\title{
EFFECT OF POTASSIEN FERTILIZER ON QUALITY AND PRODUCTIVITY OF SUGAR BEET
}

\author{
(Received : 29. 1.2013) \\ By \\ Kh. El-Sh. Mohamed and S. R. Khalil \\ Sugar Crops Research Institute-Agricultural Research Center-Giza-Egypt.
}

\begin{abstract}
A field experiment was conducted in 2010/2011 and 2011/2012 seasons at Sakha Agricultural Research Station, Kafer El-Sheikh Governorate to study the effect of Potaissien-N and/or -P fertilizers (1 litter/300 litter water/fed) as a foliar application and three potassium fertilizer rates $\left(12,24\right.$ and $\left.48 \mathrm{~kg} \mathrm{~K}_{2} \mathrm{O} / \mathrm{fed}\right)$ as soil application on quality and productivity of sugar beet (Desperes poly $\mathrm{N}$ variety). A split plot design with three replications was used, where potassien-N and/or -P were arranged in the main plots and the three potassium rates were allocated in the sub plots.

The results showed that foliar applications with potassien significantly affected yields of root and sugar (ton/ fed), and $\alpha$-amino- $\mathrm{N} \%$ in the $1^{s t}$ season, $\mathrm{Na}, \mathrm{K}$ and purity percentages in the $2^{n d}$ season, as well as sucrose $\%$ in both seasons. Potassien- $\mathrm{N}$ gave the highest root and sugar yields (ton/ fed) and sucrose $\%$ in the $1^{\text {st }}$ season, and purity $\%$ in the $2^{\text {nd }}$ season. On the contrary, it gave lowest $\mathrm{Na} \%$ in the $2^{\text {nd }}$ season. Potassium as soil application, significantly affected sugar yield (ton/ fed) and $\alpha$-amino-N $\%$ in the $1^{s t}$ season; sucrose, sugar extractable and extractability percentages in the $2^{\text {nd }}$ season, as well as $\mathrm{Na}$ and purity in both seasons. It is worth mentioning that sugar beet plants fertilized with $24 \mathrm{~kg} \mathrm{~K}_{2} \mathrm{O} / \mathrm{fed}$ maximized sugar yield in first season, and sucrose, purity, extractable sugar and extractability percentages, while $\mathrm{Na} \%$ significantly decreased in the second season. Foliar application with potassien- $\mathrm{N}$ and fertilized with potassium at rate $24 \mathrm{~kg} \mathrm{~K}_{2} \mathrm{O} /$ fed increased root yield, sugar yield, extractable sugar and extractability percentages by $30.72,43.23,16.75$ and $20.85 \%$, respectively, compared to using $48 \mathrm{~kg} \mathrm{~K}_{2} \mathrm{O} / \mathrm{fed}$ (recommended rate).
\end{abstract}

Key words: potassium fertilizer, potassien, productivity, quality, sugar beet

\section{INTRODUCTION}

In Egypt, sugar production is still insufficient for local consumption. Therefore, many attempts were devoted to improve quality and quantity of sugar beet plants, which may be done through plant fertilization. Foliar application of nutrients is one of the most important methods to substitute soil application of fertilizers, where it saves a considerable amount of nutrients lost by fixation and reduces the environmental pollution. Potassium is known for its role in sucrose transportation and accumulation in storage tissues of plants. It is one of the major elements needed for vegetative growth and sugar synthesis.

$\mathrm{K}^{+}$is considered to be the most important cation not only for its relative amounts but also for its physiological and chemical functions. This could be because $\mathrm{K}^{+}$is usually absorbed as a single charge cation by an active mechanism and it canbe translocated along electrochemical potential gradient (Roghieh and Arshad, 2009).
El-Shafai (2000) obtained significant increase in root fresh weight/plant, sugar yield and sucrose percentage as $\mathrm{K}^{+}$level was increased from zero to $48 \quad \mathrm{~kg} \quad \mathrm{~K}_{2} \mathrm{O} / \mathrm{fed}$, while root yield was insignificantly increased. Purity percentage was not significantly affected by $\mathrm{K}^{+}$fertilizer level. Ismail, et al. (2002) obtained a significant increase in root fresh weight/plant, purity\%, and root and sugar yields. Sucrose, sugar extractable and extractability \% significantly increased with application of $24 \mathrm{~kg} \mathrm{~K} 2 \mathrm{O} /$ fed and one spray of potassien nutrient solution. Ismail and Abo ElGhait (2004) obtained highly root length, sucrose $\%$, root yield and sugar yield from increasing $\mathrm{K}^{+}$ levels up to $48 \mathrm{~kg} \mathrm{~K}_{2} \mathrm{O} /$ fed. Hilal (2005) reported that root fresh weight, sucrose percentage, root and sugar yields (t/fed) increased significantly with increasing potassium fertilizer rates. Moustafa et al. (2006) found that decreasing soil application of potassium fertilizer from 24 to 12 $\mathrm{kg} \mathrm{K}_{2} \mathrm{O} / \mathrm{fed}$ gave an obvious reduction in root 
diameter, length, fresh weight, yields of root and sugar as well as root impurities content $\left(\mathrm{K}^{+}\right.$and alpha amino-N percentages) and some technological parameters (sugar loss to molasses and extractable sugar percentages), while purity $\%$ increased. Moustafa and El-Masry (2006) obtained high root and sugar yields/fed as well as sucrose $\%$, purity $\%$, and impurities content $(\alpha-$ amino- $\mathrm{N}, \mathrm{Na}^{+}$and $\mathrm{K}^{+}$) from increasing potassium level up to $48 \mathrm{~kg} \mathrm{k}_{2} \mathrm{O} / \mathrm{fed}$. Enan (2011) found that the application of $24 \mathrm{~kg} \mathrm{~K}_{2} \mathrm{O} / \mathrm{fed}+$ two sprays of potassein gave the highest values of root length, root diameter, root and top fresh weight (g/plant), as well as root, top and sugar yields/fed, purity $\%$ and sucrose \% in both seasons. Soudi et al. (2012) studied the effect of different levels of Potassien-P as foliar application and $24 \mathrm{~kg} \mathrm{~K}_{2} \mathrm{O} /$ fed to soil as a starter dose in sugar cane, they found that Potassien-P gave the highest values of purity and sugar yield (t. /fed).

This study was carried out to define the optimal rate of potassium with Potassien to reduce the pollution and achieve the highest quality and productivity of sugar beet plants under (North Delta conditions)Sakha Agricultural Experimental Research Station, Kafr El-Sheikh Governorate.

\section{MATERIALS AND METHODS}

The field experiment was conducted at Sakha Agricultural Experimental Research Station, Kafr El-Sheikh Governorate, Egypt , during 2010/2011 and 2011/2012 seasons to study the effect of potassium fertilizer as soil application and Potassien-N and/or Potassien-P as foliar application on quality and yields of sugar beet.

Soil samples were randomly taken from the experimental sites at a depth of $30 \mathrm{~cm}$ from soil surface and were prepared for both mechanical and chemical properties analyses (mean of two seasons).

The mechanical analysis was (Coarse Sand $4.95 \%$, Fine sand $17.75 \%$, Silt $31.1 \%$ and Clay $46.2 \%$ ). The soil type was silty clay. The chemical analysis was $\left(\mathrm{CaCo}_{3} 2.67 \%\right.$, E.C (1:5d $\mathrm{sm}^{-1}$ ) 3.14, $\mathrm{pH}$ 8.14, Organic Matter $1.81 \%$ and (available nutrients (ppm) were $\mathrm{Na} 28.7$, P 8.98 and $\mathrm{K} 38.7$ ). The soil tests indicated that available $\mathrm{K}^{+}$is below the optimum levels $(60-120 \mathrm{ppm})$ of the amount of potassium, where the recorded $\mathrm{K}^{+}$ was $38.7 \mathrm{ppm}$.

Soil was fertilized with $30 \mathrm{~kg} \mathrm{P}_{2} \mathrm{O}_{5} /$ fed in the form of calcium super phosphate $\left(15.5 \% \quad \mathrm{P}_{2} \mathrm{O}_{5}\right)$ during soil preparation, $90 \mathrm{~kg} \mathrm{~N} / \mathrm{fed}$ in the form of urea $(46.5 \% \mathrm{~N})$ was applied in two equal doses, after thinning and month later.
The preceding summer crop was corn in both seasons. Sugar beet was sown on 15 and 20 October 2010 and 2011, respectively.

Seeds were planted by hand in hills approximately 3-4 seed balls / hill. Plants were thinned to one plant / hill, spacing between hills was $20 \mathrm{~cm}$ after 45 days from sowing. Other cultural practices were done as recommended, in sugar beet fields.

A split plot design with three replications was used, where the potassien foliar application control ( without potassium), potassien-N (30\% $\left.\mathrm{K},{ }^{+} 8 \% \mathrm{~N}\right)$ and potassien-P $\left(30 \% \mathrm{~K}^{+}, 10 \% \mathrm{P}\right)$ at rate 1 litter/ 300 litter water/fed three times, the first after 8 weeks, the second after 10 weeks and the third one after 12 weeks age were arranged in the main plots. the three potassium rates as soil application 48 (recommended rate), 24 and $12 \mathrm{~kg}$ $\mathrm{K}_{2} \mathrm{O}$ /fed were allocated in the sub plots. Potassium fertilizer was applied in two equal doses the $1^{s t}$ one was applied before sowing and the $2^{\text {nd }}$ dose after 20 days. The sub plot area was $21 \mathrm{~m}^{2}$ consisting of 5 ridges, $7 \mathrm{~m}$ along and $60 \mathrm{~cm}$ apart. Harvest of sugar beet plants took place after 210 days from sowing in both seasons.

At harvest two guarded rows of each plot were harvested, topped and the following data were taken:

\subsection{Juice quality}

At harvest a random sample of five roots from each plot was taken and the following traits were determined.

1- Sucrose percentage ( $\mathrm{Pol} \%)$.

2- Purity \%

3- Alkalinity Coefficient (AC \%).

4- Impurities $\left(\mathrm{Na}^{+}, \mathrm{K}^{+}\right.$and $\alpha$-amino- $\left.\mathrm{N} \%\right)$.

5- Sugar extractable percentage.

6- Extractability percentage

7- Sugar loss to molasses percentage(SLM \%).

\subsection{Yields}

1. Root fresh weight $(\mathrm{kg})$

2. Root yield (tons/fed).

3. Sugar yield (tons/fed)= Root yield (tons/fed) $\mathrm{X}$ sugar extraction percentage.

Sucrose percentage ( Pol \%) was polarimetrically determined on a lead acetate extract of fresh macerated root according to the method of Le-Docte (1927). Meantime, the extract was used to determine beet impurities, sodium and potassium using Flame Photometry while $\alpha$ amino-N \% determined by Hydrindnation method according to Carruthers et al.(1962).

Purity, sugar loss to molasses percentage (SLM $\%$ ), extractable sugar percentage, extractability percentage and Alkalinity coefficient were 
calculated according to the following formulas:

Purity $\%=99.36-14.27\left(\mathrm{~K}^{+}+\mathrm{Na}^{+}+\alpha\right.$-aminoN)/ Pol (Devillers, 1988).

Sugar loss to molasses percentage $($ SLM \% $)=$ $0.343\left(\mathrm{~K}^{+}+\mathrm{Na}^{+}\right)+0.094(\alpha$-amino- $\mathrm{N})-\quad 0.31$ (Reinefeld et al, 1974).

Sugar extraction percentage $=$ Pol - SLM -0.6 (Dexter et al., 1967).

Extractability percentage $=$ Sugar extraction $/$ Pol\%.

Alkalinity coefficient $(\mathrm{AC})=(\mathrm{K}+\mathrm{Na}) /(\alpha$-aminoN)

The collected data were subjected to the proper statistical analysis of spilt plot design to compare treatments mean, LSD at 5\% level significance was used according to Steel and Torrie (1980).

\section{RESULTS AND DISCUSSION}

3.1. Effect on sucrose, purity, sugar extraction, extractability and sugar loss to molasses percentages

The effect of potassien- $\mathrm{N}$ and or-P as foliar application, potassium fertilization rates as soil application and their interaction on purity, sugar extractable $\%$ and extractability and sugar loss to molasses\% in 2010/2011 and 2011/ 2012 seasons are presented in Table 1. Data show that all mentioned traits were insignificantly affected by foliage spray sugar beet plant with potassien in both studied seasons, except sucrose \% in both seasons and purity $\%$ in the $2^{\text {nd }}$ season only. it is worth mentioning that there was no statistical difference between potassien- $\mathrm{N}$ and potassien-P on purity $\%$. Potassium fertilization at rate of 12 $\mathrm{kg} \mathrm{K}_{2} \mathrm{O} /$ fed significantly increased purity $\%$ in second season, while significantly increased extractable sugar $\%$ and extractability $\%$ in the $2^{\text {nd }}$ season only. Using $24 \mathrm{kgK}_{2} \mathrm{O} /$ fed gave the highest values compared to the recommended rate (48 $\mathrm{kgK}_{2} \mathrm{O} / \mathrm{fed}$ ), of purity, sugar extraction, extractability as $83.14,14.04$ and 72.59 in the $2^{\text {nd }}$ season. The statistical difference between 24 $\mathrm{kgK}_{2} \mathrm{O} /$ fed and $12 \mathrm{kgK}_{2} \mathrm{O} /$ fed did not reach the level of significance at $5 \%$ as shown in Table 1. Similar trend was found by Soudi et al. (2012) studying the effect of different levels of Potassien$\mathrm{P}$ as foliar application and $24 \mathrm{~kg} \mathrm{~K}_{2} \mathrm{O} / \mathrm{fed}$ to soil as a starter dose in sugar cane, they found that Potassien-P gave the highest values of purity and sugar yield (tons /fed).

Data cleared that potassium rates had a significant effect on sucrose $\%$ in the second season (Table 1). Potassium fertilizer at a rate of $24 \mathrm{~kg} \mathrm{~K} 2 \mathrm{O} /$ fed gave the highest sucrose\% in the $2^{\text {nd }}$ seasons. The positive effect of potassium applications may be due to the fact that potassium has a prevalent action in plants and it is involved in maintenance of ionic balance in cell and binds ionically to enzyme pyruvate kinase which is essential in respiration and carbohydrate metabolism (Aisha et al., 2007). The increases in sucrose content may be due to increasing photosynthesis and translocation as assimilates to storage root for $\mathrm{K}^{+}$on plant (Cooke and Scott, (1993). A similar trend was found by Moustafa et al. (2006) and Enan (2011).

The interaction between potassien and potassium applications significantly affected sucrose, purity, extractability and sugar loss to molasses percentages in the $2^{\text {nd }}$ season only, as well as sugar extraction, in both seasons (Table 1). Potassien-P and $12 \mathrm{kgK}_{2} \mathrm{O} /$ fed recorded the highest sucrose, purity, extractable sugar $\%$ and extractability $\%$ and lowest sugar loss to molasses\% compared with the other treatments.

\subsection{Effect on impurities and alkalinity coefficient \%}

The sugar beet quality depends primarily on the content of soluble amino compounds, and minerals in particular potassium and sodium. The presence of soluble amino compounds and mineral disturbs crystallization during sugar processing and thus affects the sugar output and its purity. The non- sucrose components most relevant for "technical quality: of sugar beet are potassium, sodium and $\alpha$-amino-N \% ( Europabio, 2003)

Data in Table (2) revealed that foliar application with potassien significantly affected $\alpha$ amino- $\mathrm{N} \%$ only in the $1^{s t}$ season, and $\mathrm{Na}^{+}$and $\mathrm{K}^{+}$ percentages in the $2^{\text {nd }}$ season.

Potassium fertilization as soil application significantly affected $\mathrm{Na} \%$ in both seasons and $\alpha$-amino-N $\%$ in the $1^{\text {st }}$ season only. Reducing potassium fertilizer to 24 or $12 \mathrm{~kg} \mathrm{~K}_{2} \mathrm{O} / \mathrm{fed}$ significantly reduced $\mathrm{Na} \%$ compared with $48 \mathrm{~kg}$ $\mathrm{K}_{2} \mathrm{O}$ /fed (recommended rate) in the second season. The interaction between potassien as foliar application and potassium fertilizer as soil application significantly affected alkalinity coefficient (AC) and sodium $\left(\mathrm{Na}^{+}\right)$percentages in the $1^{\text {st }}$ and $2^{\text {nd }}$ seasons, respectively.

The highest value of $\mathrm{AC}$ ( 3.19), and the lowest value of $\mathrm{Na} \%$ ( 0.97) resulted from application of potassien $\mathrm{P}$ and $12 \mathrm{~kg} \mathrm{~K}_{2} \mathrm{O} / \mathrm{fed}$.

\subsection{Effect on root fresh weight, as well as root and sugar yields}

Data in Table (3) show that foliar application with potassien exhibited significant increase in root and sugar yields ( ton / fed) only in the first season. Such increase in root yield may be 


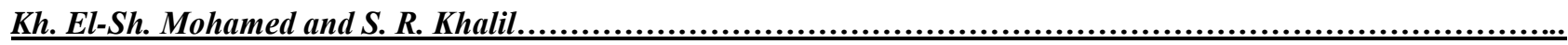

Table (1): Effect of Potassein on sucrose, purity, sugar extraction (S Ex), extractability (Ex) and sugar loss to molasses (SLM) percentages in sugar beet plants in 2010/ 2011 and 2011/ 2012 seasons.

\begin{tabular}{|c|c|c|c|c|c|c|c|c|c|c|c|}
\hline \multicolumn{2}{|c|}{ Treatments } & \multicolumn{5}{|c|}{$2010 / 2011$ season } & \multicolumn{5}{|c|}{ 2011/2012 season } \\
\hline $\begin{array}{c}\text { Foliar } \\
\text { application } \\
\text { (A) }\end{array}$ & $\begin{array}{c}\text { Soil } \\
\text { Application } \\
\text { (B) }\end{array}$ & $\begin{array}{c}\text { Sucrose } \\
\%\end{array}$ & $\begin{array}{c}\text { Purity } \\
\%\end{array}$ & $\begin{array}{c}\text { S Ex } \\
\%\end{array}$ & $\begin{array}{c}\mathbf{E x} \\
\%\end{array}$ & $\begin{array}{c}\text { SLM } \\
\%\end{array}$ & $\begin{array}{c}\text { Sucrose } \\
\%\end{array}$ & $\begin{array}{c}\text { Purity } \\
\%\end{array}$ & $\begin{array}{c}\text { S Ex } \\
\%\end{array}$ & $\begin{array}{c}\mathrm{Ex} \\
\%\end{array}$ & $\begin{array}{c}\text { SLM } \\
\%\end{array}$ \\
\hline Control & $48 \mathrm{~kg}_{2} \mathrm{O} / \mathrm{fed}$ & 14.88 & 90.06 & 13.34 & 89.67 & 0.942 & 15.04 & 76.53 & 13.27 & 88.26 & 1.167 \\
\hline \multicolumn{2}{|c|}{ Mean } & 14.70 & 83.22 & 12.84 & 87.30 & 1.262 & 14.97 & 78.23 & 13.07 & 87.28 & 1.303 \\
\hline \multirow[b]{2}{*}{ Potassein-N } & $48 \mathrm{~kg}_{2} \mathrm{O} / \mathrm{fed}$ & 15.29 & 88.08 & 13.30 & 85.98 & 1.390 & 15.23 & 82.57 & 13.15 & 86.29 & 1.480 \\
\hline & $24 \mathrm{~kg}_{2} \mathrm{O} / \mathrm{fed}$ & 18.25 & 83.24 & 16.21 & 88.74 & 1.435 & 17.67 & 86.94 & 15.94 & 90.17 & 1.131 \\
\hline \multirow[t]{2}{*}{ Potassein-P } & $24 \mathrm{kgK}_{2} \mathrm{O} /$ fed & 15.49 & 78.33 & 13.52 & 87.42 & 1.374 & 17.55 & 84.71 & 15.71 & 89.44 & 1.248 \\
\hline & $12 \mathrm{~kg}_{2} \mathrm{O} / \mathrm{fed}$ & 16.15 & 79.09 & 14.18 & 87.77 & 1.371 & 18.06 & 88.03 & 16.49 & 91.28 & 0.975 \\
\hline \multicolumn{2}{|c|}{ Mean } & 15.58 & 81.10 & 13.63 & 87.44 & 1.348 & 16.95 & 83.02 & 15.07 & 88.01 & 1.281 \\
\hline \multirow{3}{*}{$\begin{array}{c}\text { Mean } \\
\text { Of } \\
\text { Potassium }\end{array}$} & $48 \mathrm{~kg}_{2} \mathrm{O} / \mathrm{fed}$ & 15.08 & 88.00 & 13.27 & 88.00 & 1.210 & 15.17 & 78.47 & 13.15 & 86.65 & 1.423 \\
\hline & $24 \mathrm{kgK}_{2} \mathrm{O} / \mathrm{fed}$ & 16.03 & 82.34 & 14.07 & 87.65 & 1.360 & 16.64 & 83.14 & 14.78 & 88.61 & 1.267 \\
\hline & $12 \mathrm{~kg}_{2} \mathrm{O} / \mathrm{fed}$ & 15.96 & 79.01 & 13.95 & 87.28 & 1.412 & 16.62 & 83.08 & 14.78 & 88.81 & 1.240 \\
\hline \multicolumn{2}{|c|}{$\begin{array}{l}\text { L.S.D at 5\% } \\
\text { Foliar application (A) }\end{array}$} & $\begin{array}{l}1.48 \\
\text { NS } \\
\text { NS }\end{array}$ & $\begin{array}{l}\text { NS } \\
4.54 \\
\text { NS }\end{array}$ & $\begin{array}{l}\text { NS } \\
\text { NS } \\
\text { NS }\end{array}$ & $\begin{array}{l}\text { NS } \\
\text { NS } \\
2.65\end{array}$ & $\begin{array}{l}\text { NS } \\
\text { NS } \\
\text { NS }\end{array}$ & $\begin{array}{l}1.55 \\
0.87 \\
1.50\end{array}$ & $\begin{array}{l}2.68 \\
3.39 \\
5.87\end{array}$ & $\begin{array}{c}\text { NS } \\
0.80 \\
1.39\end{array}$ & $\begin{array}{c}\text { NS } \\
1.02 \\
1.73\end{array}$ & $\begin{array}{c}\text { NS } \\
\text { NS } \\
\mathbf{0 . 3 0 0}\end{array}$ \\
\hline
\end{tabular}


Table (2): Effect of Potassien on alkalinity coefficient (AC) and impurities percentages in sugar beet plants in 2010/ 2011 and 2011/2012 seasons.

\begin{tabular}{|c|c|c|c|c|c|c|c|c|c|}
\hline \multicolumn{2}{|c|}{ Treatments } & \multicolumn{4}{|c|}{$2010 / 2011$ season } & \multicolumn{4}{|c|}{ 2011/2012 season } \\
\hline \multirow{2}{*}{$\begin{array}{c}\text { Soil } \\
\text { application } \\
\text { (A) }\end{array}$} & \multirow{2}{*}{$\begin{array}{c}\text { Foliar } \\
\text { application } \\
\text { (B) }\end{array}$} & \multirow{2}{*}{$\begin{array}{c}\text { A.C } \\
\%\end{array}$} & \multicolumn{3}{|c|}{ Impurities \% } & \multirow[b]{2}{*}{ A.C\% } & \multicolumn{3}{|c|}{ Impurities \% } \\
\hline & & & $\mathrm{Na} \%$ & $\mathbf{K} \%$ & $\alpha$-amino-N \% & & $\mathrm{Na} \%$ & $\mathbf{K} \%$ & $\alpha$-amino--N \% \\
\hline \multirow[t]{3}{*}{ Control } & $48 \mathrm{~kg} \mathrm{~K}$ O/fed & 3.31 & 0.83 & 2.52 & 1.07 & 3.37 & 1.76 & 2.13 & 1.52 \\
\hline & $24 \mathrm{~kg} \mathrm{~K}_{2} \mathrm{O} / \mathrm{fed}$ & 2.97 & 1.19 & 2.96 & 1.68 & 3.70 & 1.72 & 2.92 & 1.49 \\
\hline & $12 \mathrm{~kg} \mathrm{~K}{ }_{2} \mathrm{O} / \mathrm{fed}$ & 4.82 & 1.99 & 3.14 & 1.29 & 3.79 & 1.53 & 2.79 & 1.57 \\
\hline \multicolumn{2}{|c|}{ Mean } & 3.70 & 1.34 & 2.88 & 1.35 & 3.62 & 1.67 & 2.61 & 1.53 \\
\hline \multirow[t]{3}{*}{ Potassein-N } & $48 \mathrm{~kg} \mathrm{~K}{ }_{2} \mathrm{O} / \mathrm{fed}$ & 3.46 & 1.04 & 3.51 & 1.45 & 4.01 & 1.42 & 3.43 & 1.34 \\
\hline & $24 \mathrm{~kg} \mathrm{~K}{ }_{2} \mathrm{O} / \mathrm{fed}$ & 3.17 & 1.36 & 3.23 & 1.79 & 4.58 & 1.08 & 2.89 & 0.84 \\
\hline & $12 \mathrm{~kg} \mathrm{~K}{ }_{2} \mathrm{O} / \mathrm{fed}$ & 2.88 & 1.30 & 2.88 & 1.81 & 4.06 & 1.53 & 3.18 & 1.28 \\
\hline \multicolumn{2}{|c|}{ Mean } & 3.17 & 1.24 & 3.21 & 1.69 & 4.22 & 1.34 & 3.17 & 1.15 \\
\hline \multirow[t]{3}{*}{ Potassein-P } & $48 \mathrm{kgK}_{2} \mathrm{O} / \mathrm{fed}$ & 2.83 & 1.17 & 3.02 & 1.82 & 4.55 & 1.86 & 3.41 & 1.32 \\
\hline & $24 \mathrm{kgK}_{2} \mathrm{O} / \mathrm{fed}$ & 3.16 & 1.67 & 2.73 & 1.83 & 3.69 & 1.24 & 2.97 & 1.21 \\
\hline & $12 \mathrm{~kg} \mathrm{~K}{ }_{2} \mathrm{O} / \mathrm{fed}$ & 3.19 & 1.62 & 2.79 & 1.79 & 3.75 & 0.97 & 2.51 & 0.96 \\
\hline Mean & & 3.06 & 1.49 & 2.85 & 1.81 & 4.00 & 1.36 & 2.96 & 1.16 \\
\hline Mean & $48 \mathrm{~kg} \mathrm{~K}{ }_{2} \mathrm{O} / \mathrm{fed}$ & 3.20 & 1.01 & 3.02 & 1.45 & 3.98 & 1.68 & 2.99 & 1.39 \\
\hline Of & $24 \mathrm{kgK}_{2} \mathrm{O} / \mathrm{fed}$ & 3.10 & 1.41 & 2.98 & 1.77 & 3.99 & 1.35 & 2.93 & 1.18 \\
\hline Potassium & $12 \mathrm{~kg} \mathrm{~K}{ }_{2} \mathrm{O} / \mathrm{fed}$ & 3.83 & 1.64 & 2.94 & 1.63 & 3.87 & 1.34 & 2.83 & 1.27 \\
\hline \multicolumn{10}{|l|}{ L.S.D at $5 \%$} \\
\hline \multicolumn{2}{|c|}{ Foliar application (A) } & NS & NS & NS & 0.26 & NS & 0.19 & 0.39 & NS \\
\hline \multirow{2}{*}{\multicolumn{2}{|c|}{$\begin{array}{cc}\text { Soil application } & (\mathbf{B}) \\
(\mathbf{A x B})\end{array}$}} & NS & 0.33 & NS & 0.23 & NS & 0.23 & NS & NS \\
\hline & & 0.89 & NS & NS & NS & NS & 0.39 & NS & NS \\
\hline
\end{tabular}

Table (3): Effect of Potassien on root fresh weight (kg), root and sugar yields (tons/ fed) in sugar beet plants in 2010/ 2011 and 2011/2012 seasons.

\begin{tabular}{|c|c|c|c|c|c|c|c|}
\hline \multicolumn{2}{|c|}{ Treatments } & \multicolumn{3}{|c|}{$2010 / 2011$ season } & \multicolumn{3}{|c|}{ 2011/2012 season } \\
\hline $\begin{array}{c}\text { Foliar } \\
\text { Application } \\
\text { (A) }\end{array}$ & $\begin{array}{c}\text { Soil } \\
\text { Application } \\
\text { (B) }\end{array}$ & $\begin{array}{c}\text { Root } \\
\text { Fresh } \\
\text { weight } \\
(\mathbf{k g}) \\
\end{array}$ & $\begin{array}{c}\text { Root } \\
\text { yield } \\
\text { ton/fed }\end{array}$ & $\begin{array}{c}\text { Sugar } \\
\text { yield } \\
\text { ton/fed }\end{array}$ & $\begin{array}{c}\text { Root } \\
\text { Fresh } \\
\text { weight } \\
\text { (kg) }\end{array}$ & $\begin{array}{c}\text { Root } \\
\text { yield } \\
\text { Ton/fed }\end{array}$ & $\begin{array}{c}\text { Sugar } \\
\text { yield } \\
\text { ton/fed }\end{array}$ \\
\hline \multirow[t]{3}{*}{ Control } & $48 \mathrm{~kg} \mathrm{~K} \mathrm{~K}_{2} \mathrm{O} / \mathrm{fed}$ & 0.956 & 25.367 & 3.381 & 1.084 & 23.565 & 3.128 \\
\hline & $24 \mathrm{~kg} \mathrm{~K} \mathrm{~K}_{2} \mathrm{O} / \mathrm{fed}$ & 1.176 & 22.954 & 2.855 & 1.128 & 24.939 & 3.168 \\
\hline & $12 \mathrm{~kg} \mathrm{~K}_{2} \mathrm{O} / \mathrm{fed}$ & 1.207 & 24.600 & 3.092 & 1.010 & 27.004 & 3.576 \\
\hline \multicolumn{2}{|c|}{ Mean } & 1.113 & 24.304 & 3.109 & 1.074 & 25.169 & 3.291 \\
\hline \multirow[t]{3}{*}{ Potassein-N } & $48 \mathrm{~kg} \mathrm{~K}$ O/fed & 1.264 & 24.783 & 3.297 & 1.122 & 27.587 & 3.632 \\
\hline & $24 \mathrm{~kg} \mathrm{~K}$ O/fed & 1.099 & 36.617 & 5.956 & 1.061 & 24.424 & 3.872 \\
\hline & $12 \mathrm{~kg} \mathrm{~K}$ O/fed & 0.974 & 36.167 & 5.435 & 1.164 & 21.672 & 3.156 \\
\hline \multicolumn{2}{|c|}{ Mean } & 1.112 & 32.522 & 4.896 & 1.116 & 24.561 & 3.553 \\
\hline \multirow[t]{3}{*}{ Potassein-P } & $48 \mathrm{~kg} \mathrm{~K} \mathrm{~K}_{2} \mathrm{O} / \mathrm{fed}$ & 1.189 & 32.817 & 4.355 & 1.172 & 25.800 & 3.345 \\
\hline & $24 \mathrm{~kg} \mathrm{~K}$ O/fed & 1.345 & 36.747 & 4.954 & 1.151 & 25.456 & 3.997 \\
\hline & $12 \mathrm{~kg} \mathrm{~K}$ O/fed & 1.055 & 24.350 & 3.418 & 1.150 & 22.360 & 3.673 \\
\hline \multicolumn{2}{|c|}{ Mean } & 1.196 & 31.304 & 4.242 & 1.157 & 24.539 & 3.672 \\
\hline \multirow{3}{*}{$\begin{array}{c}\text { Mean } \\
\text { Of } \\
\text { Potassium }\end{array}$} & $48 \mathrm{~kg} \mathrm{~K} \mathrm{~K}_{2} \mathrm{O} / \mathrm{fed}$ & 1.137 & 27.656 & 3.678 & 1.126 & 25.651 & 3.369 \\
\hline & $24 \mathrm{~kg} \mathrm{~K}$ O/fed & 1.206 & 32.103 & 4.588 & 1.113 & 24.940 & 3.679 \\
\hline & $12 \mathrm{~kg} \mathrm{~K}_{2} \mathrm{O} / \mathrm{fed}$ & 1.079 & 28.372 & 3.981 & 1.108 & 23.679 & 3.468 \\
\hline \multicolumn{8}{|l|}{ S.D at 5\% } \\
\hline \multirow{2}{*}{\multicolumn{2}{|c|}{$\begin{array}{l}\text { Foliar application (A) } \\
\text { Soil application }\end{array}$}} & NS & 4.895 & 0.930 & NS & NS & NS \\
\hline & & NS & NS & 0.050 & N.S & NS & NS \\
\hline & $(\mathbf{A x B})$ & NS & 7.875 & 1.225 & NS & NS & NS \\
\hline
\end{tabular}

attributed to some extent to an increase in root fresh weight. Also the role of $\mathrm{K}$ could be explained through its need as cofactor (enzymes activator) for different enzymes. In addition, $\mathrm{K}^{+}$is needed for vital processes and its beneficial effect in translocation of carbohydrates to the storage organs. (Zengin et al., 2009); Hassaanli et al., 2010).

The effect of potassium fertilizer as soil application significantly increased sugar yield in the $1^{\text {st }}$ season only. Potassium fertilizer at a rate of $24 \mathrm{~kg} \mathrm{~K}_{2} \mathrm{O} /$ fed gave the highest sugar yield 
(ton/fed). The interaction between foliar application and soil application was significant in the $1^{\text {st }}$ season. Potassium fertilizer at rate $24 \mathrm{~kg}$ $\mathrm{K}_{2} \mathrm{O}$ / fed and foliar application with potassien- $\mathrm{N}$ recorded the highest root and sugar yields (36.617and 4.894, respectively) in the $1^{\text {st }}$ season. In this connection, Enan (2011) found that the application of $24 \mathrm{~kg} \mathrm{~K}_{2} \mathrm{O} / \mathrm{fed}+$ two sprays of potassein attained the highest values of root and sugar yields/ fed in both seasons.

\section{REFERENCES}

Aisha A.H., Rizk F.A., Shaheen A.M. and AbdelMouty M.M. (2007). Onion plant growth, bulb yield and its physical and chemical properties as affected by organic and natural fertilization. Res. J. Agric. Biol. Sci., 3(5): 380-388.

Carruthers A., Oldfield J. F. T. and Teague H. J. (1962). Assessment of beet quality. Paper presented to the $15^{\text {th }}$ Annual Technical Conference, British Sugar Corporation LTD. 36 pp. ( C. F. Sugar Beet Crop Book).

Cook D. A. and Scott P. K. (1993). The sugar beet crops. Charman and Hall, London, uk.

Devillers P. (1988). Pervisiondu sucre melasse. Sucrerie francases 129. 190-200." C. F. the sugar beet crop" D. A. cooke and R. K. Scott (1993).

Dexter S. T., Franks M. G. and Snyder E. W. (1967). A rapid of determining extractable white sugar as may be applied to the evaluation of agronomic practices and grower deliveries in the sugar beet industry. J. Am., Soc., Sugar Beet Technol. 14: 433454. "C. F. The Sugar Beet Crop, world crop series, $1^{s t}$ ed. " D.A. Cooke and R.K. Scott (1993).

El-Shafai A.M.A. (2000). Effect of nitrogen and potassium fertilization on yield and quality of sugar beet in Sohag. Egypt J. Agric. Res., 78 (2): $759-767$.

Enan S.A.A.M. (2011). Effect of transplanting and foliar fertilization with potassium and boron on yield and quality traits of sugar beet sown under saline soil conditions. J. Biol. Chem. Environ. Sci., 6 (2): 525-546.

Europabio (2003). The Europabio Association for Bioindustries. Document 1-3, p.5-12.

Hassanli A. M., Ahmadirad S. and Beecham S. (2010). Evaluation of the influence of irrigation methods and water quality on sugar beet yield and water use efficiency. Agricultural Water Management, 97: 357-
362.

Hilal S. M. M. (2005). Response of sugar beet crop to application of biological and chemical fertilizers under delta north delta conditions. Ph. D. Thesis, Fac. of Agric. Kafr El-Sheikh, Tanta Univ., Egypt.

Ismail A.M.A., Aboushady Kh. A. and Allam S. M. (2002). Response of some sugar beet varieties to methods of potassium application. Egypt. J. Appl. Sci., 17(2):86101.

Ismail A.M.A. and Abo El-Ghait R. (2004). Effect of balanced fertilization of NPK on yield and quality of sugar beet. Egypt. J. Agric. Res., 82 (2): 717-729.

Le-Docte A. (1927). Commercial determination of sugar in the beet root using the sacks. LeDocte process. Int. Sug. J. 29, 488-492.

Moustafa Sh. N. and El-Masry A.A (2006). Effect of nitrogen and potassium fertilization with or without spraying by iron combined with manganese on some physio-chemical properties, productivity and quality of sugar beet crop. Annals Agric. Sci., Moshtohor 44 (4): 1431- 1446.

Moustafa Z. R., Moustafa Sh. N., Aboushady K. A. and Mohamed K. E. (2006). Effect of foliar spray with IAA and/or kinetin on physio - chemical properties and yields of sugar beet plants. Egypt. J. Agric. Res., 84 (2): 477-492.

Reinefeld E., Emmerich A., Baumgarten G., Winner C. and Beiss U. (1974). Zur Voraussage des Metassezuckers aus Rübenanalysen. Zucker, 27,2-15.

Roghieh H. and Arshad J. (2009). The K/Na replacement and function of antioxidant defence system in sugar beet (Beta vulgaris, L.) cultivars. Acta Agriculturae Scandinavica, 59 (3): 246-259.

Steel R. G. and Torrie H. H. (1980). Principles and procedures of statistics. $2^{\text {nd }}$ Ed.Megraw Hill. New York.

Soudi A. K. M., Freweez H. and Aly E. F. A. (2012). Effect of foliar application of Potassien on yield and quality of two sugar cane varieties. Egypt, J. Agric. Res., 90(1): 125-136.

Zengin M., Fatma Gokmen M., Atilla Yuzici M. and Gezgin (2009). Effect of potassium, magnesium and sulphur containing fertilizers on yield and quality of sugar beet (Beta vulgaris, L.). Turk J. Agric. 33: 495502. 


\section{تأثير التسميد بالبوتاسين على جودة وإنتاجية بنجر السكر \\ خليل الثناوى محم- سها رمضان خليل \\ معهذ بحوث المحاصيل السكرية ـ مركز البحوث الزراعية - جيزة - مصر

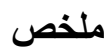

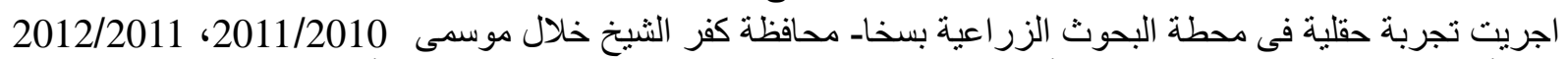

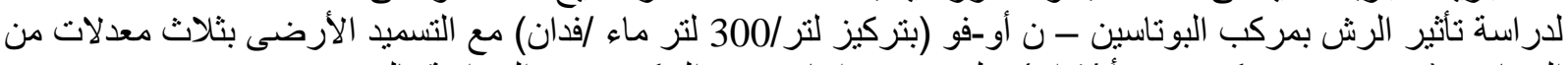

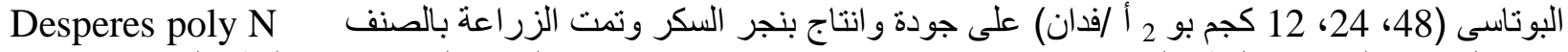

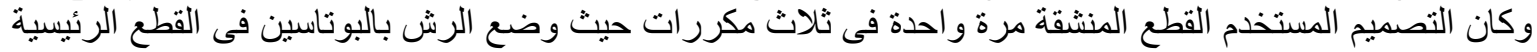

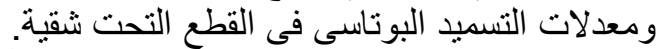

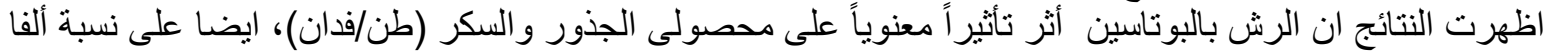

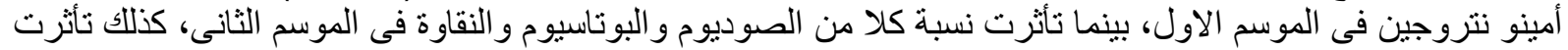

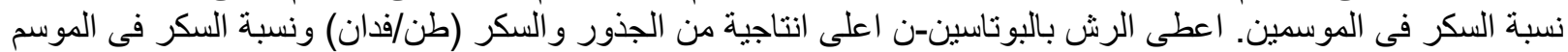

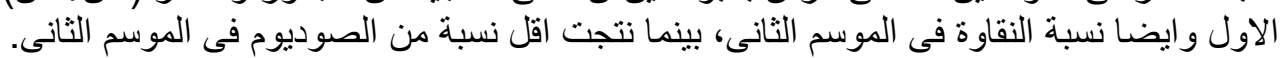

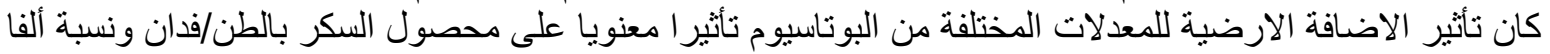

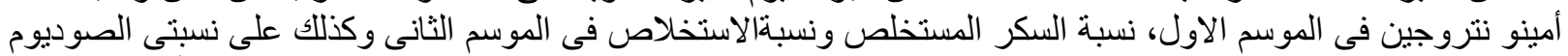

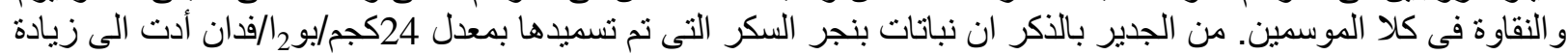

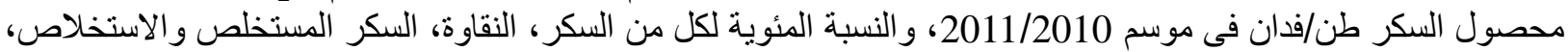

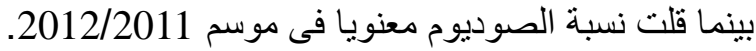

اعطت معاملة الرش بمركب البوتاسين-ن مع التسميد بمعدل 24 كجم بو 20 إ/فدان اعلى انتاجية من محصول الجذور

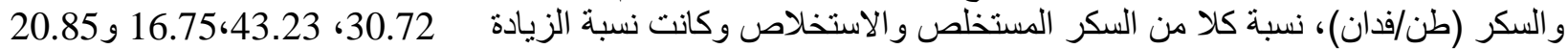

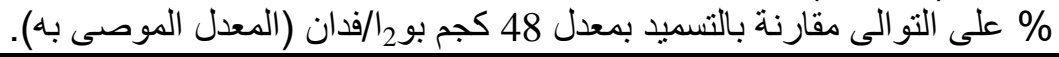

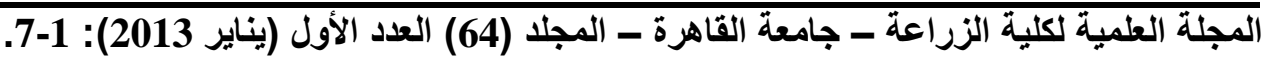

